\title{
Interregional Partnership as a Background for the Sustainable Development: European Facet
}

\author{
Zablodska Inna, Prof. Dr. ${ }^{1}$, Sieriebriak Kseniia, Dr. ${ }^{2}$, Kolomytseva Olena, Prof. Dr. ${ }^{3}$, \\ Dzhumageldiyeva Gulnara, Dr. ${ }^{4}$ and Rohozian Yuliia, Ph. D. ${ }^{1}$
}

\begin{abstract}
.
Interregional cooperation is a complex system of interconnected processes, which has begun to develop for a very long time and in the last five years, and has become relevant. This fact is also confirmed by the fact that the Association Agreement between Ukraine and the European Union includes a norm on the comprehensive development of interregional cooperation in the strategic perspective and, in most economic and legal issues; it relies on the experience of the European countries, such as Germany and Italy. Studying the world experience and identifying common economic and legal trends in the partnership implementation between regions could help Ukraine to introduce this process in practical terms and possibly avoid the most popular problems in this area. The sphere of interregional cooperation is not only economic sphere; it is a consolidation of the social sphere, economic and ecological, which is the embodiment of sustainable development of each region and the country as a whole. Value / originality. The research presents an analysis of interregional partnership in some European countries (Germany and Italy). The work compares the experience of interregional dispute implementation between the countries based on the strategic documents in this area that are related to sustainable development. Specific statistical and methodological examples of socio-economic development of the above-mentioned countries are presented in the process of establishing interregional ties. The comparative analysis of strategic subregion elements of interregional cooperation are presented and the results of the analysis by means of interval estimation are ranked. Recommendations on implementation the European experience in interregional cooperation for sustainable development in Ukraine are given. For the first time in Ukraine, the sphere of interregional partnership is analyzed not only in the light of the economy, but also through a comprehensive consideration of its economic and legal preconditions. It is expedient to use this approach, because it could be used for calculating not only the economic trends of the development of this sphere of cooperation, but also for paying attention to its legal regulation (due to the Association Agreement between Ukraine and the EU, in which interregional cooperation is one of the central places for sustainable development). Subsequently, based on these results, it would be possible to develop practical recommendations for the harmonization of Ukrainian legislation in accordance with EU legislation, which would include the economic mechanisms for the functioning of interregional cooperation and sustainable development in Ukraine.
\end{abstract}

Keyword Set: World experience, economic and legal foundations, interregional cooperation, development, strategy

${ }^{1}$ Department of Interregional Cooperation Problems, Institute of Economic and Legal Research, National Academy of Sciences of Ukraine.

${ }^{2}$ Department of Economics and Entrepreneurship, Volodymyr Dahl East-Ukrainian National University, Ministry of Education and Science of Ukraine.

${ }^{3}$ Department of Economic Cybernetics and Marketing, Cherkasy State Technological University, Ministry of Education and Science of Ukraine.

${ }^{4}$ Department of Law and Environmental Activities, Zhytomyr State Technological University, Ministry of Education and Science of Ukraine. 


\section{Introduction}

Undoubtedly, forming a unified national economic space in Ukraine is strategic and complex task, and therefore, its solution in the social, economic, ecological, political and cultural integration in the world is impossible without activating, expanding and deepening of interregional ties, institutionalization of which is a prerequisite for sustainable development inside any country in the world.

Problems of improving the quality and effectiveness of interregional relations are widely discussed in the world regional economy. However, accepted definitions of these concepts and their mutual relationship have not yet been developed, and nobody in Ukraine considered the European experience of interregional cooperation as an element of the sustainable development.

One of the most relevant regional documents in Ukraine are 'The State Strategy for Sustainable Development for the period to 2020' and 'The State Strategy for the Regional Development' approved by the Cabinet of Ministers of Ukraine on November 21, 2013. There are the strategic documents of the European model that allows harmonization and creation of an effective platform for coordination of local, regional development and their strategic goals for the sustainable development in our country. For the entire period of an independent Ukraine, for the first time, an integrated approach (social, economic and ecological spheres), based on the synergy of the three components of integrated and balanced development of the region. Synergy combines sectoral development, territorial (spatial) development and reforming public administration of regional development. Such a synergetic, institutional approach, on the one hand, allows for taking into account the specifics of resource provision in the region, the conditions and features of the placement of productive forces, and the prospects for the development of sectors at the regional level. On the other hand, these documents for the first time are identified a spatial cut of state regional policy and a managerial dimension of the regional and interregional development, which lays the foundations for the sustainable development in Ukraine.

The undoubted breakthrough is laying the foundations for the functioning of interregional partnership, but how to do it, on which documents and institutions it should be based are still nobody knows in Ukraine. Therefore, an important step is an attempt to bring this research closer to the reality of effective cooperation between the regions in Ukraine through the analysis the successful experience of the European countries.

\section{Research Methodology}

This work is based on the generalization of the official methodological information of the following countries that are the most interested for Ukraine with the economic and legal foundations of the development strategy as one of the main elements of the sustainable development, drawing attention to its imperfection. Ukraine has a new decentralization reform for the regions, which will be able to give impetus to the economic development and increase the effectiveness of the interregional ties. 
The methodology of the cooperation between regions in the chosen countries is based on four levels of knowledge: general philosophical level (set of common views and knowledge about phenomena related to the development strategy and interregional cooperation); general scientific level (understanding of common approaches, principles, economic cooperation forms) and specific methodology of sciences (aggregate economic and legal European experience in the cooperation between regions).

Also, the research is based on methods of comparison and analysis (in the context of practical experience in the interregional partnership for the sustainable development), groupings and graphical method of information processing (in the context of the strategy programs and plans realization in the Germany and Italy), is based on official normative legal acts, scientific and practical research of leading scientists and economists (Blume L.; Loschiavo D.; Min M.; Doidge M. and others).

\section{German experience at the interregional partnership}

Speaking about the formation and implementation process of the development strategy as one of the main elements of the sustainable development, the understanding of the definitions 'development' and 'development strategy' is the top priority. A large number of scientists have studied this concept; most of them agree that 'development' is the ability of an object, process, or phenomenon to purposefully modify its properties and functions to improve current characteristics under the influence of external and internal factors. This category is often associated with the notion of 'change', which means the absence of objects and processes with absolutely identity with themselves, as well as their spatial position over time; can be positive and negative.

Many European scientists taking into account different approaches considered the concept of the strategy in the regional context. Summarizing the provisions of foreign studies, the following definition of a strategy could be presented: a systematic description of the main goals of the subject (territorial unit), priorities and tasks, the main problems and ways to solve them for sustainable development in the long term. The development strategy is considered as the main instrument for implementing regional policies and interregional relations in the European countries and as a purposeful, qualitative, substantial improvement of the system and / or its elements, properties and relationships in the long term.

The main tools for the formulation and implementation the development strategy of the regional and interregional policy in the EU countries are the following: investment grants, interest rate subsidies (Belgium, Germany, Greece, Norway, Portugal, UK), tax incentives (Finland, France, Greece, Italy), tax discount on depreciation (Greece), laborrelated subsidies (Austria, Belgium, France, Ireland, Sweden, Great Britain), cross-border benefits (Finland, Sweden), etc. (Małkowska, A. and Głuszak, M., 2016).

For such a successful European country as Germany, there is a high degree of centralization, that is, the significant role of the central level of government in the country's sustainable development. The experience of the development strategy of the interregional partnership in Germany is interesting by the stability of social, economic and ecological ties between the center and the regions. The system of the interregional cooperation was formed because of the reforms in 1969 and did not change in principle. 
Even after the unification of Germany, new lands were excluded from the general rules for interregional redistribution of funds only until 1995, since the special fund for the support of the eastern lands 'German Unity (Deutsche Einheit)' existed only in 19901994.

In Germany, there is currently no separate state authority on interregional issues - this is the direction of the German federal policy that is occupied by the Ministry of Economy (since 2013 the Federal Ministry of Economics and Energy - German Bundesministerium für Wirtschaft und Energie). The legal definitions of the 'interregional cooperation' or 'sustainable cooperation of the regions' are also absent in Germany. However, on the website of the Ministry of Economy and Energy of Germany, one can find information that 'interregional policy is a mutual stand-up policy aimed at the economic development of the shtandarts (regions)' (in translation from the German 'shtandart' - placement or location). As in other European countries, the cooperation of German regions is aimed at supporting economically underdeveloped territories and ensuring equal living conditions both within each region and throughout the country.

In fact, the policy of the interregional cooperation in Germany boils down to two components: the implementation of the regional policy of the EU and the overall strategy for the regions development named 'Improvement of the regional economic structure'.

The existence of such an overall development strategy was enshrined in the Basic Law of Germany (in Article 91a) as far back as 1969, and at the present time only two of these strategic development tasks remain, next to the above, 'Improving the Agrarian Structure and Protecting the Coastlines'. The main tasks of the development strategy 'Improvement of the regional economic structure' (hereinafter referred as the 'Strategy') are financed from the federal budget, and its commonality is expressed not only in cofinancing the Strategy from the federal and land budgets, but also in the joint participation of the authorities of several regions in the social, economic and ecological relevant activities. At the same time, such areas of the interregional cooperation are supported: industrial infrastructure of the regions, general innovation development, assistance to rural areas of the country and measures aimed at forming sectoral and territorial associations to ensure economic cooperation between regions (for example, the formation of clusters).

The Strategy as an instrument of social, economic and ecological interaction between German regions has been working for almost 50 years, which indicates its sustainable development, stability and effectiveness. However, the framework plans for the implementation of this document are reviewed every few years: the composition of the supported territories, the principles of their selection are adjusted, the areas of cooperation between certain regions are revised, and the parameters for supporting problem areas are reviewed. Recently, such framework plans were approved for 7 years 2000-2006, 2007-2013 and 2014-2020. That is, they are synchronized with the EU's multi-year plans.

The experience of the German development strategy of the interregional cooperation is interesting in its approaches to the selection of a group of territories that are becoming objects of sustainable support. Firstly, the analysis of the current situation is conducted 
in the regions in those areas of the economy that are most in demand against the backdrop of labor migration. It is unusual that in the country with a sufficiently developed interregional policy is not limited to a grid of administrative-territorial units, and engaged in economic zoning. In addition, the allocation of these or those lands is based on the calculation of the integral indicator reflecting the structural problems of the labor markets in these regions. Therefore, in the framework plan for the implementation of the Strategy for 2014-2020 thirteen of the Germany lands have received the financial support in the context of the joint economic cooperation (Table 1).

Table 1. The German lands participation in the interregional partnership (the plan 2014-2020)

\begin{tabular}{ll}
\hline Land name & Share of the received support, $\%$ \\
\hline Bavaria & 1,59 \\
Berlin & 10,85 \\
Brandenburg & 12,45 \\
Bremen & 1,51 \\
Hesse & 2,29 \\
Mecklenburg-Western Pomerania & 10,14 \\
Lower Saxony & 3,46 \\
North Rhine-Westphalia & 1,43 \\
Rhineland-Palatinate & 19,99 \\
Saxony-Anhalt & 13,85 \\
Schleswig-Holstein & 6,51 \\
Saxony & 12,18 \\
Thuringia & 3,75 \\
\hline Total & 100,00 \\
\hline Calculated by the authors (based on The European Commission, 2017 and The Federal Statistical Office of \\
Germany, 2017)
\end{tabular}

Among all instruments of interregional cooperation in Germany, measures to support the socio-economic development of different regions associated with the deployment of public authorities are particularly noteworthy, because this country is an example where the decentralization of the state structures deployment is successfully practiced. Thus, federal agencies are located in 28 German cities in the different regions. At the same time, such placement is not unevenly process: 10 offices are located in the capital Berlin, 22 agencies are located in Bonn and its suburbs, 11 in the North Rhine-Westphalia region, and 10 in neighboring Lower Saxony. In Bavaria and Rhineland-Palatinate there are 3 departments, in Baden-Württemberg and Hamburg - 2, in Schleswig-Holstein - 1. Unlike Ukraine, in the German legal framework there are no strategies for the sustainable development of individual territories. In addition to the above-mentioned national Strategy, there are interregional programs, plans and other documents regulating the issues of the development strategy for the interregional cooperation between German lands. Therefore, the main current programs are: 
1. 'The Amalgamated Development Program between Regions of Ruhr and Saar'. The priority of implementing this program is the joint strengthening in social and economic policies: social guarantees for the unemployed, additional payments to enterprises for the workers retraining, support for the reconstruction process and socio-economic reorientation of the cities in these regions, the creation of a joint social infrastructure in education, health, sports;

2. 'The Regional Development Plan of North Rhine-Westphalia, Hesse and Lower Saxony'. The basis for the implementation of this plan is financial support for codevelopment in the new technologies for coal mining and increasing interregional investments (to preserve the competitiveness of the coal industry);

3. Strategic Development Program for 2010-2020 'The Action Program in Ruhr and Thuringia'. This document is implemented for reducing the unemployment rate in the regions, developing new amalgamated technologies and introducing innovations, joint measures to protect the environment in industrial regions, stimulating interregional investment activity;

4. 'The Regional System Creation of the Innovations Program'. The program basis is the effective interaction between universities, scientific and business sector in the three regions: Brandenburg, Saxony, Saxony-Anhalt;

5. 'The Plan for the New Cluster Development - a Center for the Environmental and Economic Technologies'. The necessity of the high technologies development covers the implementation of the activities in Mecklenburg-Western Pomerania, Bremen, Hesse and Lower Saxony regions, not only within large industrial enterprises, but also in the sphere of small and medium-sized business;

6. Interregional Program 'The Emscherpark Ecological Development'. The main activities of this program cover the territories of the Bremen and Hessen regions in the context of environmental protection: revitalization of waterways and coastal zones, contaminated by industrial enterprises in the regions; creation of a co-system including new scientific and technological centers in place of old industrial facilities; creation of a general landscape park Emscher and seven green corridors, serve as the links between the major regional centers of the country (Rheinisch-Westfälisches Institut für Wirtschaftsforschung, Stifterverband für die Deutsche Wissenschaft, 2006 and IAT, ÖIR, EPRC, 2003).

The implementation of these development programs could be considered a successful practice for the sustainable development in terms of achieving the following results: reduction of the social tension level caused by the low level of the regional development and the rapid growth of unemployment; improvement of the technological base of enterprises in traditional industries based on the interregional experience; implementation of the interregional infrastructure projects that could create a solid foundation for further social, economic and ecological development between regions.

\section{Interregional partnership bases in Italy}

Another European experience in the development strategy implementation belongs to Italy, first of all, due to the large development disproportion of the territory, lags far behind the national average indicators for socio-economy-ecological 
development (the South of Italy - the Mezzogiorno region). Such situation is the result of the late arrivals in the economic transformations (including later industrialization) and socio-cultural characteristics (criminogenic situation, shadow economy and others), which push the region away from internal and external investors.

Italy consists of 20 regions that make up five major socio-economic regions, namely the Northeast, the Northwest, the Center, the South and the Islands. Mezzogiorno is a region of the South, including the Apennine peninsula islands (Basilicata, Campania, Calabria, Apulia, Molise, Abruzzo, Sicily and Sardinia). In the south of the country, incomes per capita are 1.8 times lower than in the most developed North-West region, and 1.5 times lower than the national average (Table 2). At the same time during 20122016 (according to official statistics), the differences between the Italian regions in terms of the household incomes remained practically unchanged.

Table 2. Per capita income in the Italian regions for the period 2012-2016, euros

\begin{tabular}{llllll}
\hline Name of the socio-economic region & 2012 & 2013 & 2014 & 2015 & 2016 \\
\hline Northeast & 19300 & 23500 & 22000 & 22100 & 21500 \\
Northwest & 22600 & 23100 & 21900 & 21900 & 21000 \\
Center & 25600 & 20800 & 19800 & 19800 & 19100 \\
South and Islands (Mezzogiorno) & 16700 & 12900 & 12200 & 12200 & 13500 \\
\hline
\end{tabular}

Calculated by the authors (based on the Organization for Economic Co-operation and Development, 2018 and The Statistics Portal, 2018)

The Mezzogiorno region is also characterized by a high level of unemployment, which in recent years has more than doubled compared to North-West (Table 3). Moreover, the gap between the unemployment rates of Mezzogiorno and the North-West, just as in Italy on average, has only increased in recent years.

Table 3. The unemployment rate in the regions of Italy for the period 2013-2017 (percentage of the total population)

\begin{tabular}{llllll}
\hline Name of the socio economic region & 2013 & 2014 & 2015 & 2016 & 2017 \\
\hline Northeast & 6,2 & 8,3 & 8,0 & 8,9 & 8,7 \\
Northwest & 7,5 & 8,0 & 6,7 & 7,7 & 7,5 \\
Center & 11,9 & 11,2 & 12,0 & 10,9 & 11,0 \\
South and Islands (Mezzogiorno) & 22,8 & 23,3 & 20,9 & 19,3 & 19,2 \\
average unemployment rate in the country & 12,1 & 12,7 & 11,9 & 11,7 & 11,6 \\
\hline
\end{tabular}

Calculated by the authors (based on the Organization for Economic Co-operation and Development, 2018 and The Statistics Portal, 2018)

The indicators for which the Mezzogiorno region lags behind the more developed regions of the central and northern Italy could be extended. However, the above data is enough to confirm that the problem of the regional imbalances in Italy is topical. Therefore, Italy's interregional policy is focused, first of all, not on the sustainable development, but on solving the problem of economic weakness in the southern regions. The importance of the Italian regional policy and the interregional relations lies in the fact that the EU has own forms for the territorial cooperation, which is being 
implemented at the national level in Italy. However, the general principles of the coordination between regions in the EU countries does not abolish the urgency to formulate and implement a development strategy for the sustainable development; on the contrary, the EU policy is rather a complement to the national regional and interregional policy.

EU regulations do not require the inclusion of the regional and socio-economyecological development indicators in strategic and national documents, but only in operational programs and regulations of a local nature (to gain an opportunity to assess the progress of regional and interregional development based on the local authorities). However, Italy preferred to develop cooperation between its regions in the strategic dimension in several directions at once, including relevant goals, priorities and indicators both in operational programs and in the National Strategic Framework. Approximately 80 indicators, classified according to ten priorities, in which some general regional tasks are performed, designed to measure the changes that have occurred in the regions. Such priorities include the following: increase of the labor efficiency in the regions and development of the labor resources, development of the innovations research, sustainable development and efficient use of environmental resources, socio-economic provision of the services quality and living standards in the regions, careful attitude to natural resources and culture in the regions, communication and transport infrastructure, competitiveness and attractiveness of cities and regions, openness and attraction of interregional investments, management, institutions and an effective market, ecological situation (Loschiavo, D., 2016 and Blume, L., 2006).

Over the past three years, interest to interregional cooperation between the Italian regions has significantly increased - it was possible to overcome the old practice when some structural elements of the regional strategic development (tasks, indicators) were used by local authorities only to meet EU requirements. Now, on the contrary, the local regional authorities are actively involved in the process of developing strategic documents to strengthen interregional cooperation and sustainable development in Italy. The main institution that provides technical and financial support for solving problems in the interregional cooperation and policy in Italy is The Underdeveloped Regions Foundation (Fondo per le aree sottoutilizzate). To these territories, except for 8 parts of the Mezzogiorno region, which account for $85 \%$ of the Fund's resources, there are some areas of the Northeast of the country. The Interdepartmental Committee for Economic Planning deals with the issues of sustainable development in this institution. It directs the financial resources of the Fund between three components, each of which corresponds to one of the objectives: the infrastructure and ecological fund (Fondo infrastrutture e ambientale), the strategic fund for support and development of the real economy (Fondo strategico per il Paese a sostegno dell'economia reale), the supporting fund of the employment and education (Fondo sociale per l'occupazione e la formazione) (Table 4). 
Table 4. The financial structure of the strategic directions in the Italian interregional policy 20162017

Directions and priorities of the interregional policy

Share of the total financing, $\%$

1. Improvement of labor efficiency in the regions and 14,9

development of labor resources

2. Development of research and innovations 12,4

3. Sustainable development and use of environmental resources 10,2

4. Socio-economic support for the services quality and living 17,4 standards in the regions

5. Careful attitude to the regional environment and culture $\quad 6,4$

6. Communication and transport infrastructure 4,7

7. Competitiveness and attractiveness of the cities and urban 14,0

systems

8. Openness and attraction of the interregional investments 13,6

9. Management, institutions and efficient market $\quad 6,4$

\begin{tabular}{ll}
\hline Total & 100
\end{tabular}

Calculated by the authors (based on the Organization for Economic Co-operation and Development, 2018 and The Statistics Portal, 2018)

Considerable attention in Italy is paid to the effectiveness monitoring of the measures and tasks to ensure the cooperation development between the regions in the strategic dimension. To assess the implementation quality of the regional and interregional policies, The National System for the Investment Evaluation and Monitoring has been established, which operates both at the regional and national levels. To ensure transparency in the use of the financial sources, the special database 'Regional Public Accounts' (Conti Pubblici Territoriali, CPT) was created as a composite system of the national statistics. To enhance efficient use of resources, an assessment of the individual effectiveness and joint activities of the local authorities was made in the regions. However, the monitoring system is often criticized because its results are insufficient to assess the measures effectiveness. The results of the monitoring only reflect what was done during the program, but not the effect that was caused by this program. For the same reason, it is difficult to assess the measures effectiveness taken at this stage, it would be possible to judge effect in the sustainable development only over time. Currently, Italy also lacks the unified development strategy of the interregional cooperation, but there are a lot of elements of the sustainable development in the regions. The strategic role play the following programs and activities:

1. 'The Program Directions and Priorities in the Development Assistance for 2009-2019'. The basis of this document is the cooperation of the Campania, Calabria and Puglia regions in the social and economic sphere, the environment protection, the public goods development and support in these regions;

2. 'The Innovation and Investment Program for the Umbria, Tuscany, Basilicata and Veneto Development'. The basis of this cooperation is the co-activities implementation to attract investors in the new technologies, products and services, the staff exchange between the innovative enterprises in the regions, etc.; 
3. 'The Education Development Program' covers the territories of the two Italian regions - Valle d'Aosta and Veneto, which are strongly considered in the field of education. Therefore, the priority of this program is the staff and experience exchange among the different universities;

4. 'The Effective Aid Plan to the Assist Areas' provides for the experience exchange from the economically developed areas of Italy (Trentino-Alto Adige, Sicily, Sardinia, Piedmont, etc.) to the developing areas (Friuli-Venezia Giulia, Abruzzo) (The European Investment Bank, 2013).

Thus, the Italian interregional policy is the complex system that has a sustainable measurement, funded at the national and regional levels with direct cooperation between different levels of government. The appropriate organizational structures have been created to implement the interregional policy that helps to develop the relevant regional programs and activities. This process helps to equalize the interregional imbalances in Italy, which are now quite significant. However, for the effective development in the interregional relations, there is a lack of the integrated strategic documents that would come out ahead the social, economic and ecological situation in the Italian regions as a whole.

\section{Conclusions}

In the presented countries, there is no pure practice in Developing Strategies for the sustainable development, they are replaced by programs and action plans, but it cannot fully replace strategic plans and actions in the long term. However, as analysis of European experience in this area shows some elements of the cooperation among regions for the sustainable development; they are already present at the Table 6.

Table 6. Comparative analysis of the interregional elements for the sustainable development in the European countries

The main interregional elements

$\begin{array}{llll}\text { Availability } & \text { of } & \text { Availability } \\ \text { elements } & \text { in } & \text { of } \\ \text { documents } & \text { in } \\ \text { (Germany) } & & \begin{array}{l}\text { documents } \\ \text { (Italy) }\end{array} & \end{array}$

1. Strategic analysis of the regions state in the context of their sustainable (social, economic and ecological) cooperation:

1.1 SWOT-analysis, PESTLE- analysis

1.2 Analysis of the socio-economic and ecological conditions in the regions

1.3 Analysis of the regional interaction with stakeholders

1.4 Diagnostics of innovation (analysis of the current state and dynamics of the innovative state and potential in the sustainable cooperation among regions)

2. Strategic doctrine of the interregional cooperation

2.1 Mission 


\begin{tabular}{|c|c|c|}
\hline 2.2 Principles & + & + \\
\hline 2.3 Objectives & + & + \\
\hline $\begin{array}{l}\text { 2.4 Priorities and directions of innovative } \\
\text { development between regions }\end{array}$ & + & - \\
\hline $\begin{array}{l}2.5 \text { Identification the main problems and ways to } \\
\text { solve them }\end{array}$ & + & + \\
\hline $\begin{array}{l}\text { 2.6 Scenarios for innovation and sustainable } \\
\text { development }\end{array}$ & - & - \\
\hline $\begin{array}{l}2.7 \text { Orientation to National Strategic Planning } \\
\text { Documents }\end{array}$ & + & + \\
\hline $\begin{array}{l}\text { 3. System of measures and implementation of } \\
\text { strategic tasks in the cooperation between regions: }\end{array}$ & & \\
\hline $\begin{array}{l}\text { 3.1 Target indicators for the strategic objectives } \\
\text { implementation }\end{array}$ & - & - \\
\hline $\begin{array}{l}3.2 \text { Implementation mechanism and monitoring of } \\
\text { the strategic objectives }\end{array}$ & - & - \\
\hline $\begin{array}{l}\text { 3.3 Risks in the implementation of planned tasks, } \\
\text { measures to minimize their negative impact }\end{array}$ & - & - \\
\hline $\begin{array}{l}\text { 4. Effectiveness of the strategic tasks implementation } \\
\text { in the cooperation among regions }\end{array}$ & & \\
\hline $\begin{array}{l}\text { 4.1 A working plan of measures for the interregional } \\
\text { cooperation implementation and its development }\end{array}$ & + & + \\
\hline $\begin{array}{l}\text { 4.2 Managing the innovative and sustainable } \\
\text { development of the cooperation between regions }\end{array}$ & - & - \\
\hline $\begin{array}{l}\text { 4.3 Effectiveness of the funds spent on the } \\
\text { development and implementation of strategic tasks. }\end{array}$ & - & - \\
\hline
\end{tabular}

Source: own elaboration

In order, to comprehensively assess the level of strategic support for sustainable development between regions, it is necessary to evaluate the elements listed in Table 7 on an interval scale from ' -5 ' to '5', where the boundary points reflect the following values:

- '-5' - complete absence of the necessary element and mechanisms for its implementation, despite the existence of its regulation in the concerned country;

- '0' - complete absence of the necessary element and mechanisms for its implementation, in the absence of its regulation in the concerned country;

- '5' - availability of the necessary element and mechanisms for its implementation at a sufficient level for its evaluation and analysis.

Each of the submitted elements is given an appropriate quantitative evaluation, then the indicators are summarized, the average scores are calculated in each of the 4 blocks of indicators for each country. The results of a comprehensive assessment of the strategic provision level for the economic cooperation between regions are presented in Figure 1. 


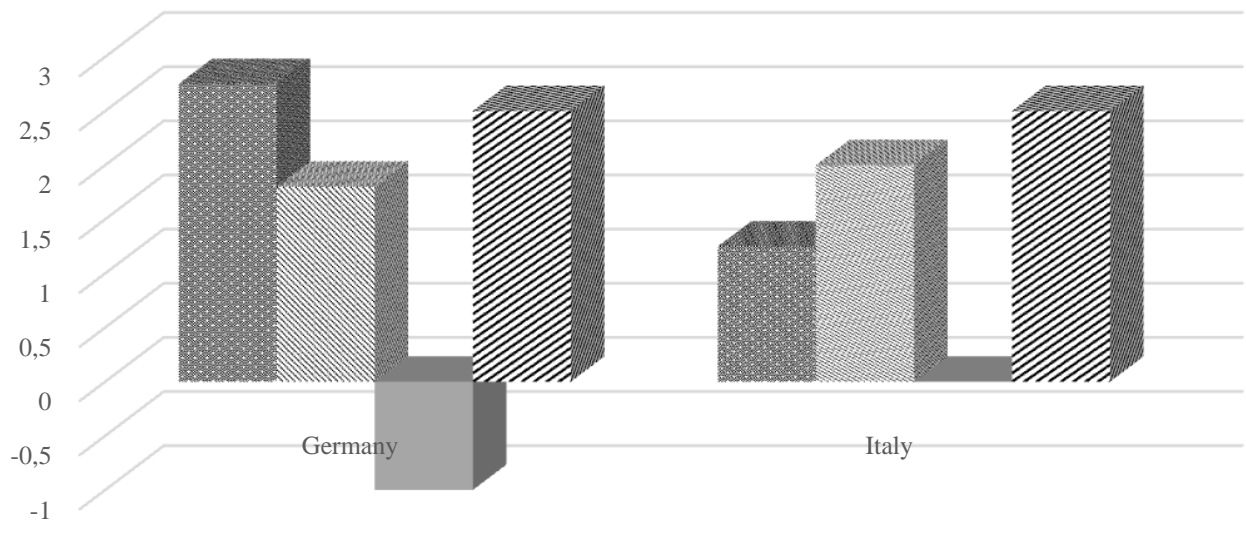

Strategic analysis

Strategic doctrine

Measures system and tasks implementation Performance of assignments

Fig. 1 The comprehensive assessment results of the interregional support level for the sustainable development Source: own elaboration

After the analysis, it is important to note that practically both countries pay considerable attention to the analysis of the innovative state and sustainable development in the different strategic documents (average score is 2.0 for both countries). As the main weakness of the analytical block of most strategic documents, there is a lack of the target settings analysis of all sustainable development stakeholders between regions and their specifics in the current socio-economic situation of the represented countries. Also important is the fact that in the documents of each country the questions of the strategic doctrine of interregional cooperation have been thoroughly worked out (average score is 1.5). Nevertheless, at the same time, attention is drawn to the absence of an essential element of the strategic development - a clearly formulated mission for the cooperation between regions and their sustainable development.

The problematic aspect of all the above-mentioned countries is also a component of the implementation effectiveness of the strategic tasks, where there are basically no necessary plans. Thus, strategic foundations for the interregional partnership of the represented countries are already laid. Nevertheless, in order to really develop and pay dividends to the stakeholders, it is necessary to formulate and adopt a unified development strategy that will correlate with both national and local documents for the sustainable development in every country.

Obviously, it is impossible to reduce the differences in income and living standards of the population without reducing the differences in the regional levels, clearly manifested in interregional cooperation. As European experience shows, interregional policy and sustainable development in any country should differ in the following features: the presence of a conscious and formulated goals vision of this process; the existence of authorities that are responsible for changing the regional territorial proportions; 
availability of the special tools aimed at raising problem areas in a strategic dimension of the sustainable development.

There are many instruments of the interregional policy; they are different in each country. In Ukraine, as in other European countries, the interbudgetary relations are developing, accompanied by a common problem for many countries to find a compromise between equalizing the regional budget provision and creating incentives for local authorities to pursue an effective social, economic and ecological policy. Having studied the European experience, one can see that the sustainable and interregional processes are somewhat conflicting and opposite to each other, so it is important to determine the characteristics of their coexistence: parallelism, complementarity or mutual exclusion. Currently, none of the above processes in Ukraine has received a dominant character; both are still slowly and partially developed. However, it is already possible to trace two interesting contradictory tendencies: decentralization becomes a catalyst for regionalization processes, contributes to the allocation of regional identities and activation acquire of communication between regions in various spheres. Then, we hope that interregional cooperation in Ukraine will become a full part of the sustainable development with its legal field, system components, purpose and mechanisms, which will be further ground for scientific research.

\section{References}

Blume, L. (2006) Local Economic Policies as Determinants of Local Business Climate: Empirical Results from a Cross-section Analysis among East German Municipalities. Regional Studies, vol. 40 (4), pp. 321-333. doi: 10.1080/00343400600725178

Loschiavo, D. (2016) Household debt and income inequality: evidence from Italian survey data. Publishing Division of the Bank of Italy. 47 p.

Min, M. (2017) The Revival of China: (with Pictures). Independently published. 570 p.

Doidge, M. (2014) Interregionalism and the European Union: conceptualizing group-to-group relations. Intersecting Interregionalism: regions, global governance and the EU. Dordrecht: Springer, pp. 37-54.

Małkowska, A. and Głuszak, M. (2016) Pro-investment Local Policies in the Area of Real Estate Economics - Similarities and Differences in the Strategies Used by Communes. Oeconomia Copernicana, vol. 7 (2), pp. 269-283. doi: 10.12775/OeC.2016.016

The European Commission (2017). Regional South Strategy Paper (2014-2020) and Multiannual Indicative. Retrieved from http://eeas.europa.eu/archives/docs/enp/pdf/financing-theenp/regional south strategy paper 20142020 and multiannual indicative programme 20142 017 en.pdf. last visited 25 Apr 2018.

The Federal Statistical Office of Germany (2017) The regional databank. Statistics. Retrieved from https://www.regionalstatistik.de/genesis/online/online;jsessionid=.worker1?sequenz=statistiken \&selectionname $=71^{*}$. last visited 25 Apr 2018

Rheinisch-Westfälisches Institut für Wirtschaftsforschung, Stifterverband für die Deutsche Wissenschaft (2006), Innovationsbericht. Zur Leistungsfähigkeit des Landes Nordrhein-Westfalen in Wissenschaft, Forschung und Technologie, Essen. 23 p.

IAT, ÖIR, EPRC (2003), Halbreitbewertung des Ziel 2-Programms des Landes Nordrhein-Westfalen-Abschlussbericht, Gelsenkirchen, Wien und Strathclyde. Zur Leistungsfähigkeit des Landes Nordrhein-Westfalen in Wissenschaft, Forschung und Technologie, Essen. 35 p.

Organization for Economic Co-operation and Development (2018) Housebold disposable income. Data. Retrieved from https://data.oecd.org/hha/household-disposable-income.htm. last visited $25 \mathrm{Apr}$ 2018. 
The Statistics Portal (2018) Italy: Unemployment rate from 2007 to 2017. Retrieved from https://www.statista.com/statistics/263699/unemployment-rate-in-italy/. last visited $25 \mathrm{Apr}$ 2018.

The European Investment Bank (2013) JESSICA 2014-2020 MultiRegion Study for Italy Marche, EmiliaRomagna, Lazio, Veneto). Final Report. Retrieved from http://www.eib.org/attachments/documents/jessica italy multi region en.pdf. last visited 25 Apr 2018.

Federal Reserve Bank of St. Louis (2017). Economic Research Data. Retrieved from https://fred.stlouisfed.org/categories/27281. last visited 25 Apr 2018.

Pacific Northwest Regional Economic Analysis Project (2017). United States - Year vs. Year Analysis of Total Employment Growth and Change, 1958-2017. Retrieved from https://unitedstates.reaproject.org/analysis/comparative-indicators/year vs year/total employment/.__last visited 25 Apr 2018.

Grigoriev, L. (2013) Scenarios of Economic Institutions Development. Economy Policy. vol. 3, pp. 33-60.

Euromoney Institutional Investor Company (CEIC) (2018) China GDP per Capita 1957 - 2017. Retrieved from https://www.ceicdata.com/en/indicator/china/gdp-per-capita. last visited 25 Apr 2018. 